\title{
Korelasi Kadar Vitamin D, dengan TNF- $\alpha$ dan Manifestasi Klinis pada Pasien Artritis Rematoid
}

\section{The Correlation of Vitamin D, TNF- $\alpha$, and Clinical Manifestation in Rheumatoid Arthritis Patients}

\author{
Hanik Ruliani ${ }^{1}$, Handono Kalim ${ }^{1}$, BP Putra Suryana ${ }^{1}$, Kusworini Handono ${ }^{2}$ \\ ${ }^{1}$ Divisi Rematologi dan Imunologi Bagian Ilmu Penyakit Dalam Rumah Sakit Umum Dr. Saiful Anwar Malang \\ ${ }^{2}$ Laboratorium Patologi Klinik Fakultas Kedokteran Universitas Brawijaya
}

\begin{abstract}
ABSTRAK
Artritis rematoid (AR) adalah penyakit autoimun yang ditandai dengan sinovitis erosif simetrik, diawali dengan aktivasi sel T dependent antigen yang akan mencetuskan respon imun, terutama tipe Th1. Tumor necrosis factor (TNF- $\alpha$ ) adalah sitokin sentral pada patogenesis AR. Diketahui bahwa defisiensi vitamin D berkaitan dengan eksaserbasi respon imun Th1. Penelitian ini bertujuan untuk mengetahui korelasi kadar vitamin D dengan kadar TNF- $\alpha$, beratnya aktivitas penyakit pada pasien rematoid artritis. Penelitian cross sectional dilakukan pada pasien rawat jalan yang memenuhi kriteria inklusi sebanyak 24 pasien, kriteria diagnosis ditegakkan menurutkriteria ACR/EULAR 2010. Vitamin D dalam darah dan TNF- $\alpha$ diukur dengan metode ELISA, beratnya manifestasi klinis penyakit AR dinilai dengan score DAS28, VAS, dan skala fungsional. Sebesar 45,8\% pasien mengalami defisiensi vitamin $D(36,13 \mathrm{ng} / \mathrm{ml})$. Gangguan fungsional terbanyak adalah kelas I (66,6\%). Terdapat korelasi yang bermakna antara vitamin $D$ dengan usia pasien $(p=0,005, r=-0,553)$, dengan lama sakit ( $p=0,009, r=-0,522)$, dengan DAS $28(p=0,001, r=-0,615)$, banyaknya sendi yang sakit $(p=<0,001, r=-0,733)$, dan sendi yang bengkak ( $p=0,045, r=-0,413)$, VAS pasien $(p=0,006, r=-0,541)$ serta dengan kadar TNF $(p=0,048, r=-0,408)$ dan status fungsional pasien $(p=0,039, r=-0,424)$. Hasil membuktikan bahwa kadar vitamin $D$ dalam darah mempunyai hubungan dengan manifestasi klinis AR dan kadar TNF
\end{abstract}

Kata Kunci: Artritis rematoid, DAS 28, CRP, TNF VAS, vitamin D

\begin{abstract}
Rheumatoid arthritis is an autoimmune disease which is initiated by T-cell dependent antigen activation that lead to Th1 immune response type. Tumor necrosis factor is the central cytokine in the AR pathogenesis. This research aimed to investigate the correlation between vitamin D, TNF- $\alpha$ and the clinical severity of rheumatoid arthritis. A cross sectional design was performed in 24 out-patients subject that meet diagnosis criteria based on ACR/EULAR 2010. The level of vitamin D and TNF- $\alpha$ were measured using ELISA method while the AR clinical manifestation was measured using DAS 28 score, VAS and functional scale. Result shows vitamin D deficiency in 45,8\% patients, and 66,6\% with class I functional alteration. Vitamin D level have significant correlation with patients age $(p=0,005, r=-0,553)$, length of sickness ( $p=0,009$, $r=-0,522), D A S(p=0,001, r=-0,615)$, number of joint involved, swallow joint $(p=0,045, r=-0,413), \operatorname{VAS}(p=0,006, r=-0,541)$, TNF- $\alpha$ level $(p=0,048, r=-0,408)$ and patients functional status $(p=0,039, r=-0,424)$. It can be concluded that vitamin $D$ level have a significant correlation with TNF- $\alpha$ and clinical manifestation in rheumatoid arthritis.
\end{abstract}

Keywords: DAS 28, CRP, Rheumatoid Arthritis, TNF VAS, vitamin D

Jurnal Kedokteran Brawijaya, Vol. 28, No. 1, Februari 2014; Korespondensi: Hanik Ruliani. Divisi Rematologi dan Imunologi Bagian IImu Penyakit Dalam Rumah Sakit Umum Dr. Saiful Anwar Malang, Jl. Jaksa Agung Suprapto No. 2 Malang Tel. (0341) 357663 Email: hanikruliani@gmail.com 


\section{PENDAHULUAN}

Interaksi antara vitamin $D$ dengan sistem imun merupakan hal yang sedang menjadi fokus perhatian (1). Insufisiensi vitamin D berkembang menjadi masalah global, dan secara epidemiologi, status vitamin D berhubungan dengan kecenderungan dan beratnya penyakit autoimun (2). Berkembang upaya untuk mengetahui dan memahami peran vitamin $D$ diluar fungsinya dalam homeostasis kalsium, diantaranya dalam penyakit autoimun (3).

Artritis rematoid (AR) merupakan penyakit rematik autoimun yang ditandai oleh sinovitis erosif yang simetris dan pada beberapa kasus disertai dengan keterlibatan jaringan ekstraartikular (4). Prevalensi dan insidensi penyakit ini bervariasi antara populasi satu dengan lainnya. Di Eropa, prevalensi AR sekitar 1\%. Di Malang, pada penduduk usia diatas 40 tahun prevalensinya sebesar 0,5\%, dan di RSUPN Cipto Mangunkusumo Jakarta tahun 2000 kasus baru artritis rematoid sebesar 4,1\% dari seluruh kasus baru. Sebagian besar pasien menunjukkan gejala penyakit kronik yang hilang timbul, yang jika tidak diobati akan menyebabkan terjadinya kerusakan sendi dan deformitas sendi yang progresif yang menyebabkan disabilitas (5).

Tumour necrosis factor (TNF- $\alpha$ ) adalah sitokin sentral pada patogenesis AR. Peran TNF- $\alpha$ pada patogenesis AR yang banyak dipelajari dan paling banyak diketahui adalah tentang kemampuannya untuk memicu inflamasi. Pasien AR mempunyai kadar TNF- $\alpha$ yang tinggi dalam cairan sendinya dan ini memegang peranan utama dalam inflamasi dan kerusakan sendi pada artritis rematoid $(6,7)$. Hipotesis penelitian ini adalah terdapat korelasi antara kadar vitamin D dengan kadar TNF- $\alpha$ dan beratnya manifestasi klinis pada pasien artritis rematoid.

\section{METODE}

Rancangan penelitian ini adalah survey dengan pengumpulan data secara potong-lintang. Sampel penelitian adalah pasien artritis rematoid yang berkunjung di Poliklinik Rematologi RSU Dr. Saiful Anwar Malang pada bulan Januari-Juni 2012, direkrut dengan metode sampling konsekutif setelah mendapatkan penjelasan dan menandatangani informed consent. Penelitian ini telah disetujui oleh Komite Etik Penelitian Kesehatan RSU Dr. Saiful Anwar Malang. Diagnosis artritis rematoid ditegakkan dengan kriteria ACR/EULAR 2010 dan memenuhi kriteria inklusi dan eksklusi (8).

Selama periode penelitian didapatkan 24 pasien artritis rematoid yang memenuhi kriteria inklusi, meliputi wanita, usia 16 sampai 60 tahun. Kriteria eksklusi meliputi: menderita infeksi berat (dari gejala klinis menunjukkan infeksi yang berat atau peningkatan leukosit), penyakit liver (peningkatan SGOT dan SGPT $>3 x$ nilai normal), gangguan fungsi ginjal (peningkatan creatinin $>2 x$ nilai normal), dan tidak mengkonsumsi obat vitamin D. Kadar vitamin D adalah kadar $25(\mathrm{OH}) \mathrm{D}$ yang diukur dalam serum dengan metoda Enzyme Immuno Assay (DiaSorin Inc, Stillwater, MN,USA), defisiensi bila kadar vitamin D $<30 \mathrm{ng} / \mathrm{ml}$. Kadar CReactive Protein (CRP) diukur dengan metode Elisa dengan cutoff normal $<0,3 \mathrm{mg} / \mathrm{dl}$. TNF- $\alpha$ diukur dari serum dengan metode ELISA. Hasil pengukuran TNF- $\alpha$ dinyatakan dalam kadar $(\mathrm{pg} / \mathrm{mL})$. VAS dievaluasi dengan menggunakan pain scale 0-100 mm. Aktivitas penyakit diukur dengan DAS(28)-CRP dikelompokkan sebagai berat bila DAS $28 \geq 3$,2, dan ringan bila DAS28 $<3,2(9,10)$. Status fungsional pasien AR dinilai berdasarkan revisi klasifikasi fungsional dari American College of Rheumatology 1991, yaitu kelas I sampai kelas IV (11). Lama sakit diperhitungkan dalam bulan. Hubungan antara kadar vitamin D dengan kadar TNF- $\alpha$ dan beratnya aktivitas penyakit pasien artritis rematoid dianalisa dengan uji korelasi Pearson distribusi data normal, dan uji korelasi Spearman bila distribusi data tidak normal menggunakan program SPSS for Windows Release 17.0.

\section{HASIL}

Sebesar $45,8 \%$ pasien pada penelitian menunjukkan defisiensi vitamin $D$, dengan rata-rata kadar vitamin $D$ pasien $36,13 \mathrm{ng} / \mathrm{ml}$. Rerata usia pasien AR adalah 51 tahun, rata-rata $\mathrm{BMI} 22,90 \mathrm{~kg} / \mathrm{m}^{2}$ dan pasien yang underweight sebanyak 20,8\%. Dari hasil penelitian didapatkan bahwa sebagian besar pasien menopause $(66,7 \%)$, dengan lama sakit rata-rata 51,29 bulan dan telah mendapatkan terapi methotrexate selama rata-rata 28,62 bulan, dan semua pasien mendapatkan terapi methothrexate, sedangkan pasien yang mendapatkan terapi NSAID sebanyak 91,7\%, dan methylprednisolon sebanyak 83,3\% (Tabel 1).

Tabel 1. Karakteristik klinis subjek penelitian $(n=24)$

\begin{tabular}{cc}
\hline \multicolumn{1}{c}{$\begin{array}{c}\text { Karakteristik pasien } \\
\mathbf{n = 2 4}\end{array}$} & mean \pm SD; prosentase \\
\hline Umur (tahun) & $51,04+8,17(26-60)$ \\
BMI $\left(\mathrm{kg} / \mathrm{m}^{2}\right)$ & $22,90 \pm 5,60(13,40-33,80)$ \\
BMI $<18,5$ & $20,8 \%$ \\
BMI 18,5-23 & $37,5 \%$ \\
BMI>23 & $41,7 \%$ \\
Lama sakit (bulan) & 51,29 \\
Lama terapi (bulan) & 28,62 \\
Terapi $\quad 24(100 \%)$ \\
Methothrexate & $20(83,3 \%)$ \\
Methylprednisolone & $22(91,7 \%)$ \\
NSAID & $8(33,3 \%)$ \\
Status Menopause & $16(66,7 \%)$ \\
Premenopause &
\end{tabular}

Rerata usia pasien AR adalah 51 tahun, rata-rata BMI $22,90 \mathrm{~kg} / \mathrm{m}^{2}$ dan pasien yang underweight sebanyak $20,8 \%$. Dari hasil penelitian didapatkan bahwa sebagian besar pasien menopause $(66,7 \%)$, dengan lama sakit ratarata 51,29 bulan dan telah mendapatkan terapi methotrexate selama rata-rata 28,62 bulan, dan semua pasien mendapatkan terapi methothrexate, sedangkan pasien yang mendapatkan terapi NSAID sebanyak $91,7 \%$, dan methylprednisolon sebanyak 83,3\%.

Tabel 2. Gambaran klinis dan laboratoris pasien artritis rematoid

\begin{tabular}{lc}
\hline \multicolumn{1}{c}{ Karakteristik } & Proporsi $(\mathbf{n = 2 4 )}$ atau mean+SD(range) \\
\hline Jumlah sendi nyeri (TJC) & $12 \pm 5,90$ \\
Jumlah sendi bengkak (SJC) & $2 \pm 2,40$ \\
Visual Analogue Scale (VAS) & $45 \pm 16,60$ \\
CRP (mg/dl) & $1,24 \pm 1,89$ \\
DAS 28 & $3,29 \pm 0,71$ \\
\hline
\end{tabular}


Tabel 2. Gambaran klinis dan laboratoris pasien artritis rematoid (Lanjutan)

\begin{tabular}{lc}
\hline \multicolumn{1}{c}{ Karakteristik } & Proporsi ( $\mathbf{n} \mathbf{2 4})$ atau mean+SD(range) \\
\hline Hemoglobin (g/dl) & $12,39 \pm 1,14$ \\
Ureum ( & $23,22 \pm 8,86$ \\
Creatinin ( & $0,65 \pm 0,16$ \\
SGOT ( & $18,70 \pm 4,83$ \\
SGPT ( & $18,04 \pm 6,85$ \\
Vitamin D (ng/ml) & $36,13 \pm 18,61$ \\
Defisiensi & $11(45,8 \%)$ \\
normal & $13(54,2 \%)$ \\
TNF (pg/mL) & $15,32 \pm 4,33$ \\
Rematoid factor & \\
Positif & $15(6,2,5 \%)$ \\
Negatif & $9(37,5 \%)$ \\
Kelas I & \\
Kelas II & $16(66,6 \%)$ \\
Kelas III & $6(25 \%)$ \\
Kelas IV & $1(4,2 \%)$ \\
& $1(4,2 \%)$ \\
\hline
\end{tabular}

Terdapat korelasi yang bermakna antara vitamin $\mathrm{D}$ dengan usia pasien $(p=0,005, r=-0,553)$, dengan lama sakit $(p=0,009, r=-0,522)$ dan lama terapi $(p=0,046, r=-0,411)$, dengan DAS 28 (CRP) $(p=0,000, r=-0,694)$, banyaknya sendi yang sakit $(p=0,000, r=-0,788)$, dan sendi yang bengkak ( $p=0,045, r=-0,413)$, VAS pasien $(p=0,006, r=-$ $0,541)$ serta dengan kadar TNF $\alpha \quad(p=0,048, r=-0,408)$ dan status fungsional pasien $(p=0,039, r=-0,424)$.

Tabel 3. Korelasi kadar vitamin D dengan karakteristik pasien artritis rematoid

\begin{tabular}{lcc}
\hline \multirow{2}{*}{ Variabel } & \multicolumn{2}{c}{ Korelasi } \\
\cline { 2 - 3 } & $\mathbf{r}$ & $\mathbf{p}^{*}$ \\
\hline Umur (tahun) & $-0,553$ & $0,005^{*}$ \\
BMI (kg/m²) & 0,781 & 0,183 \\
Lama sakit (bulan) & $-0,577$ & $0,009^{*}$ \\
Lama terapi (bulan) & $-0,411$ & $0,046 *$ \\
DAS28 (CRP) & $-0,694$ & $0,000^{*}$ \\
TJC & $-0,788$ & $0,000^{*}$ \\
SJC & $-0,413$ & $0,045^{*}$ \\
LED & 0,064 & 0,768 \\
Hb (g/dL) & 0,041 & 0,851 \\
Visual Analogue Scale (VAS) & $-0,541$ & $0,006^{*}$ \\
TNF (pg/mL) & $-0,408$ & $0,048^{*}$ \\
Rematoid Factor & $-0,073$ & 0,914 \\
Status fungsional & $-0,424$ & $0,039^{*}$ \\
\hline
\end{tabular}

\section{DISKUSI}

Pada penelitian ini didapatkan umur rata-rata pasien AR adalah 51 tahun, hal ini sesuai dengan literatur bahwa angka kejadian tertinggi AR didapatkan pada dekade keempat dan kelima, pada penelitian ini sebesar 79,4\% (5). Defisiensi vitamin D pada pasien AR cukup tinggi, yaitu sebesar $45,8 \%$. Hasil ini sesuai dengan penelitian yang dilakukan multi center, dengan prevalensi defisiensi vitamin D pada pasien AR berkisar antara 30-63\% (12). Hasil analisis dari beberapa penelitian epidemiologi didapatkan bahwa konsentrasi $25(\mathrm{OH}) \mathrm{D}$ yang optimal untuk kesehatan tulang dan kebutuhan ekstra skeletal antara $36-40 \mathrm{ng} / \mathrm{ml}$ (13). Kadar ini didapatkan pada 45,8\% pasien penelitian kami. Ini berarti bahwa pada hasil penelitian kami didapatkan sebagian besar pasien AR (54,2\%), mempunyai kadar vitamin D yang kurang optimal untuk mempertahankan kesehatan tulang dan kebutuhan ekstra skeletal.

Hasil penelitian ini juga menunjukkan bahwa vitamin $D$ berhubungan dengan lamanya sakit dan lamanya terapi dari AR. Vitamin $D$ juga berhubungan dengan sendi yang bengkak dan nyeri, hal ini sesuai dengan hasil penelitian yang dilakukan oleh Craig et al, yang menemukan hubungan antara vitamin $D$ dengan nyeri, sendi yang bengkak dan aktivitas penyakit (14).

Pada penelitian ini didapatkan korelasi bermakna antara kadar vitamin $D$ dengan beratnya aktivitas penyakit, semakin tinggi kadar vitamin D maka aktivitas penyakit semakin rendah. Penelitian yang dilakukan oleh Rossini, Patel et al, pada pasien yang jauh lebih besar jumlahnya, juga menemukan korelasi antara kadar vitamin D dengan beratnya aktivitas penyakit. Penelitian tersebut juga menemukan korelasi yang signifikan antara kadar vitamin $D$ dengan jumlah sendi yang nyeri dan bengkak, serta status fungsional pasien (HAQ score) $(12,15)$. Dengan semakin tinggi kadar vitamin D maka jumlah sendi yang bengkak dan nyeri semakin berkurang, mempengaruhi juga terhadap penurunan VAS pasien dan juga berpengaruh terhadap status fungsional pasien $A R$.

Dalam penelitian ini didapatkan korelasi yang signifikan antara kadar vitamin D dengan kadar TNF- $\alpha$. Patologi dasar pada sinovium pasien AR adalah hiperplasi, peningkatan vaskuler dan infiltrasi sel inflamasi. TNF- $\alpha$ merupakan sitokin kunci dalam patogenesis AR (7). TNF- $\alpha$ diproduksi terutama oleh monosit dan makrofag yang teraktivasi, tetapi juga oleh sel $B$, sel T, dan fibroblas. TNF- $\alpha$ mampu menginduksi sitokin proinflamasi lain, termasuk IL-1 dan IL-6, bersama dengan kemampuannya untuk menginduksi produksi dan pelepasan kemokin yang menarik leukosit dari darah ke dalam jaringan inflamasi $(6,16)$. Peran TNF- $\alpha$ pada beberapa sel pada artritis rematoid diantaranya terhadap makrofag akan menginduksi proliferasi dan meningkatkan produksi sitokin. Peran TNF- $\alpha$ terhadap sel T yang teraktivasi akan meningkatkan proliferasi dan meningkatkan reseptor IL-2. Pada sel B akan terjadi peningkatan proliferasi dan diferensiasi, dan terhadap sel dalam sinovium akan menginduksi proliferasi, sintesis IL-1, granulocyte monocyte-colony stimulating factor, kolagenase dan prostaglandin. Pada sel endotelial akan terjadi induksi ekspresi intracellular adhesion molecule 1, vascular cell adhesion molecule 1, endothelial leucocyte adhesion molecule-1 (ELAM-1) dan IL-8 (7).

Vitamin D dapat menghambat monosit maupun makrofag untuk mengeluarkan sitokin proinflamasi, juga menghambat limfosit $\mathrm{T}$ dalam produksi sitokin pro inflamasi, dalam penelitian ini adalah TNF- $\alpha$. Ekspresi VDR ditemukan pada sambungan kartilago dan pannus pada pasien $A R$, dan berhubungan dengan berbagai tipe sel, diantaranya kondrosit, makrofag, fibroblas sinoviosit, sel B dan sel endotelial (17). Pada penelitian terhadap hewan coba (tikus) yang diinduksi artritis ditemukan bahwa tikus yang diberi 1,25 $(\mathrm{OH}) 2 \mathrm{D} 3$ menunjukkan artritis yang lebih ringan (18). Pada penelitian yang lain juga menemukan bahwa monosit pada tikus yang tidak mempunyai VDR, memproduksi TNF- $\alpha$ dan IL-1 yang lebih banyak (19). 1,25 
$(\mathrm{OH}) 2 \mathrm{D} 3$ menghambat proliferasi sel $\mathrm{T}$, diferensiasi sel T menjadi Th 1 dan sekresi sitokin proinflamasi seperti TNF $\alpha$, IL-2 dan IFN $\gamma$ (20). Vitamin D aktif juga menghambat polarisasi dan aktivitas Th $17(21,22)$. Efek vitamin $D$ terhadap TNF- $\alpha$ juga ditunjukkan dalam penelitian Zhu et al, pada percobaan binatang dengan inflammatory bowel disease, 1,25(OH)2D mampu menghambat beberapa gen yang berkaitan dengan TNF$\alpha$, termasuk protein yang terlibat dalam transkripsi TNF$\alpha$, salah satu dari reseptor utamanya, dan TNF- $\alpha$ itu sendiri (23).

Pada penelitian yang dilakukan oleh Bar-Shavit dan kawan-kawan, makrofag yang didapatkan pada tikus yang mengalami defisiensi vitamin $\mathrm{D}$ menunjukkan gangguan fungsi. Vitamin $D$, baik secara in vivo maupun in vitro menginduksi diferensiasi monosit/makrofag $(24,25)$. Mononuklear fagosit memegang peranan penting dalam inisiasi dan mempertahankan respon imun serta memproduksi berbagai molekul aktif, termasuk sitokin seperti TNF- $\alpha$ (26). Ekspresi TNF- $\alpha$ diatur oleh mekanisme transkripsional dan post transkripsional (27).

Vitamin D merupakan hormon steroid dengan reseptor di nukleus (nuclear receptor). Nuclear receptor mempunyai kemampuan untuk mengikat DNA secara langsung dan mengatur ekspresi dari gen yang terikat, sehingga reseptor ini termasuk dalam kelompok transcriptional factor. Reseptor ini bersama dengan protein mengatur transkripsi gen spesifik, yang pada akhirnya dapat mengontrol perkembangan, homeostasis, dan metabolisme organisme. Nuclear receptor mempunyai 6 domain (domain A sampai $F$ ), dengan salah satu domain berfungsi sebagai ligan binding domain (LBD) yang akan berikatan dengan ligannya, dan terdapat DNA binding domain (DBD), yang akan berikatan dengan sekuens DNA sel target pada daerah yang disebut hormone response elements (HRE).

Semua organ target vitamin D, termasuk sel imun, memiliki reseptor vitamin $D$ pada inti selnya (VDR). Ekspresi VDR terdapat pada sebagian besar jaringan pannus dan kartilago pada pasien artritis rematoid. VDR memiliki afinitas terhadap 1,25(OH)2D 1000 kali lebih besar daripada terhadap metabolisme vitamin D lainnya. Setelah mencapai organ target, 1,25(OH)2D akan terlepas dari protein pengikatnya, kemudian masuk kedalam sel dan berinteraksi dengan VDR. Kompleks 1,25(OH)2D-VDR akan berinteraksi lagi dengan retinoic acid $X$ receptor (RXR) membentuk heterodimer yang kemudian akan berinteraksi dengan vitamin D-responsive element (VDRE) didalam DNA. Interaksi ini akan menghasilkan transkripsi dan sintesis mRNA baru, yang pada akhirnya dapat

\section{DAFTAR PUSTAKA}

1. Marques CD, Dantas AT, Fragoso TS, and Duarte AL. The Importance of Vitamin D Levels in Autoimmune Diseases. The Brazilian Journal of Rheumatology. 2010; 50(1): 67-80.

2. Cutolo M. Vitamin $D$ and Autoimmune Rheumatic Diseases. Rheumatology. 2009; 483: 210-212.

3. Deluca HF and Cantorna MT. Vitamin D; Its Role and Uses in Immunology. The Journal of Federation of American Societies for Experimental Biology. 2001; 15(14): 2579-2585. mengontrol perkembangan, homeostasis, dan metabolisme sel target. Bagian VDR yang berikatan dengan $1,25(\mathrm{OH}) 2 \mathrm{D}$ adalah pada daerah terminal $\mathrm{C}$, yang disebut hormone binding domain, sedangkan bagian yang berikatan dengan DNA adalah pada daerah terminal N, yang disebut DNA binding domain yang memiliki jari-jari Zn $(5,28,29)$. Vitamin D mungkin juga dapat menghambat proliferasi sel B serta menjaga homeostasis sel B (30).

Vitamin D juga berhubungan dengan umur. Hal ini mungkin berkaitan dengan semakin tua usia, produksi vitamin $D$ oleh kulit juga akan semakin berkurang karena konsentrasi 7-DHC (dehydrocholesterol) yang tidak teresterifikasi berkurang (5). Vitamin D juga berhubungan dengan lamanya sakit, dimana semakin lama sakit, maka kadar vitamin D semakin rendah. Penelitian yang dilakukan oleh Oleson dan Patel tentang kadar vitamin $\mathrm{D}$ pada pasien trauma dengan spinal cord injury, menunjukkan bahwa pasien dengan spinal cord injury kronis mempunyai kadar vitamin $\mathrm{D}$ yang lebih rendah diandingkan dengan pasien dengan spinal cord injury akut (31). Hal ini mungkin berhubungan dengan simpanan vitamin $D$ yang ada sebelum sakit dan berhubungan dengan aktivitas di luar rumah yang lebih sering dilakukan sebelum pasien sakit. Adanya hubungan yang terbalik antara kadar vitamin D dengan kadar TNF- $\alpha$ yang merupakan sitokin proinflamasi utama dalam patogenesis $A R$, akan berpengaruh terhadap proses inflamasi yang terjadi, yang akhirnya akan berpengaruh terhadap manifestasi klinis yang terjadi pada pasien AR.

Desain penelitian yang terbaik untuk melihat hubungan antara kadar vitamin D dengan kadar TNF $\alpha$ dan beratnya aktivitas penyakit pada pasien AR adalah desain studi survei dengan pengambilan data secara kohort prospektif, namun mengingat keterbatasan waktu dan biaya maka dilakukan pengambilan data secara potong lintang. Pada penelitian ini obat-obatan merupakan salah satu variabel perancu yang tidak dikontrol. Untuk memperkecil pengaruh variabel tersebut, sebaiknya penelitian menggunakan sampel penderita AR dengan obat-obatan yang sama. Pada penelitian ini semua pasien menggunakan DMARDs yang sama, namun mengingat keterbatasan jumlah penderita AR yang didapat, maka penggunaan steroid maupun NSAID tidak dikontrol.

Hasil penelitian membuktikan kadar vitamin D berkorelasi dengan kadar TNF- $\alpha$ dan beratnya manifestasi klinis pasien artritis rematoid. Semakin rendah kadar vitamin D pada pasien AR, semakin tinggi kadar TNF- $\alpha$ nya dan semakin berat aktivitas penyakit, derajat nyeri serta juga keterbatasan dalam melakukan aktivitas kehidupan sehari-hari.

4. Buch M and Emery P. The Aetiology and Pathogenesis of Rheumatoid Arthritis. Hospital Pharmacist. 2002; 9: 5-9.

5. Linda W. Arthritis Rheumatoid. Di dalam: Aru W, Bambang S, Idrus A, Marcellus S, dan Siti S (Eds). Buku Ajar Ilmu Penyakit Dalam edisi 5. Jakarta: Penerbit FKUI; 2009: hal. 203-226.

6. Brennan FM and McInnes IB. Evidence that Cytokines Play a Role in Rheumatoid Arthritis. The Journal of Clinical Investigation. 2008; 118(11): 3537-3545.

7. VasanthiP, NaliniG, and Rajasekhar G. Role of Tumor 
Necrosis Factor-Alpha in Rheumatoid Arthritis: A Review. Asia Pacific League of Associations for Rheumatology Journal of Rheumatology. 2007; 10(4): 270-274.

8. Daniel A, Tuhina N, and Silman AJ. Rheumatoid Arthritis Classification Criteria. Arthritis \& Rheumatism. 2010; 62(9): 2569-2581.

9. Aletaha D and Smolen J. Outcome Assessment in Rheumatic Disease. In: Smolen JS and Lipsky PE(Eds). Contemporary Targeted Therapy in Rheumatology. London: Informa Healthcare; 2007; pp. 601-616.

10. Jaclyn Anderson, Liron Caplan, Jinoos Yazdan, et al. Rheumatoid Arthritis Disease Activity Measures: American College of Rheumatology Recommendations for Use in Clinical Practice. Arthritis Care \& Research. 2012; 64(5): 640-647.

11. Hochberg MC, Chang RW, Dwosh I, Lindsey S, Pincus T, and Wolfe F. The American College of Rheumatology 1991 Revised Criteria for the Classification of Global Functional Status in Rheumatoid Arthritis. Arthritis and Rheumatism. 1992; 35(5): 498-502.

12. Rossini M, Maddali BS, La Montagna G, et al. Vitamin $D$ deficiency in Rheumatoid Arthritis: Prevalence, Determinants, and Association with Disease Activity and Disability. Arthritis Research \& Therapy. 2010; 12(6): R216.

13. Bischoff-Ferrari HA, Giovannucci E, Willett WC, Dietrich $\mathrm{T}$, and Dawson-Hughes B. Estimation of Optimal Serum Concentrations 25-Hydroxyvitamin D for Multiple Health Outcomes. The American Journal of Clinical Nutrition. 2006; 84(1): 18-28.

14. Craig SM, Yu F, Curtis JR, et al. Vitamin D Status and its Associations with Disease Activity and Severity in African Americans with Recent Onset Rheumatoid Arthritis. The Journal of Rheumatology. 2010; 37(2): 275-281.

15. Patel S, Farragher T, Berry J, Bunn D, Silman A, and Symmons D. Association between Serum Vitamin $D$ Metabolite Levels and Disease Activity in Patients with Early Inflammatory Polyarthritis. Arthritis \& Rheumatology. 2007; 56(7): 2143-2149.

16. Kinne RW, Bräuer R, Stuhlmüller B, Kinne EB, and Burmester GR. Macrophages in Rheumatoid Arthritis. Arthritis Research \& Theraphy. 2000; 2(3): 189-202.

17. Tetlow LC, Smith SJ, Mawer EB, and Woolley DE. Vitamin $D$ Receptors in the Rheumatoid Lesion: Expression by Chondrocytes, Macrophages, and Synoviocytes. Annals of the Rheumatic Diseases. 1999; 58(2): 118-121.

18. Cantorna MT, Hayes CE, and Deluca HF. 1,25Dihydroxycholecalciferol Inhibits the Progression of Arthritis in Murine Models of Human Arthritis. The
Journal of Nutrition. 1998; 128(1): 68-72.

19. Zwerina K, Baum W, Axmann R, et al. Vitamin D Receptor Regulates TNF-Mediated Arthritis. Annals of the Rheumatic Diseases. 2011; 70(6): 1122-1129

20. Rigby WF, Stacy $\mathrm{T}$, and Fanger MW. Inhibition of $T$ Lymphocyte Mitogenesis by 1,25-Dihydroxyvitamin D3 (Calcitriol). The Journal of Clinical Investigation. 1984; 74(4): 1451-1455.

21. Colin EM, Asmawidjaja PS, and van Hamburg JP. 1,25Dihydroxyvitamin D3 Modulates Th17 Polarization and Interleukin-22 Expression by Memory T Cells from Patients with Early Rheumatoid Arthritis. Arthritis \& Rheumatology. 2010; 62(1): 132-142.

22. Van Hamburg JP, Asmawidjaja PS, Davelaar N, et al. TNFa Blockade Requires 1,25(OH)2D3 to Control Human Th17-Mediated Synovial Inflammation. Annals of the Rheumatic Diseases. 2012; 71(4): 606-612.

23. Zhu Z, Mahon BD, Froicu M, and Cantorna MT. Calcium and 1a,25-Dihydroxyvitamin D3 Target the TNF-A Pathway to Suppress Experimental Inflammatory Bowel Disease. European Journal of Immunology. 2005; 35(1): 217-224.

24. Abu-Amer $Y$ and Bar-Shavit Z. Regulation of TNF-A Release from Bone Marrow-Derived Macrophages by Vitamin D. Journal of Cellular Biochemistry. 1994; 55(4): 435-444.

25. Cohen ML, Douvdevani A, Chaimovitz C, and Shany S. Regulation of TNF-Alpha by 1 Alpha, 25Dihydroxyvitamin D3 in Human Macrophages from CAPD Patients. Kidney International. 2001; 59(1): 69-75.

26. Beutler BA. The Role of Tumor Necrosis Factor in Health and Disease. Journal of Rheumatology Supplement. 1999; 57: 16-21.

27. Anderson P. Post-Transcriptional Regulation of Tumour Necrosis Factor Alpha Production. Annals of the Rheumatic Diseases. 2000; 59(1): 3-5.

28. Carlberg C, Bendik I, Wyss A, et al. Two Nuclear Signaling Pathways for Vitamin D. Nature. 1993; 361(6413): 657-660.

29. Wu Y, Craig TA, Lutz WH, and Kumar R. Identificationof 1 Alpha, 25-Dihydroxyvitamin D3 Response Elementsin the Human Transforming Growth Factor-Beta 2 Gene. Biochemistry. 1999; 38(9): 2654-2660.

30. Chen S, Sims GP, Chen XX, Gu YY, Chen S, and Lipsky PE. Modulatory Effects of 1,25-Dihydroxyvitamin D3 on Human $B$ Cell Differentiation. The Journal of Immunology. 2007; 179(3); 1634-1647.

31. Oleson CV, Patel PH, and Wuermser L. Influence of Season, Ethnicity, and Chronicity on Vitamin $D$ Deficiency in Traumatic Spinal Cord Injury. The Journal of Spinal Cord Medicine. 2010; 33(3): 202-213. 